\title{
Clinical features of 47 patients infected with COVID-19 admitted to a Regional Reference Center
}

\author{
FELIPE OLIVARES ${ }^{1}$, DANIEL MUÑOZ ${ }^{2,3}$, ALBERTO FICA ${ }^{1,4}$, \\ IGNACIO DELAMA ${ }^{1,4}$, IGNACIA ALVAREZ ${ }^{5}$, MARITZA NAVARRETE ${ }^{6,7}$, \\ EILEEN BLACKBURN ${ }^{8}$, PAMELA GARRIDO ${ }^{7}$, RICARDO WENGER $^{9}$, \\ JUAN GRANDJEAN ${ }^{4,10}$
}

\begin{abstract}
Background: During the first pandemic wave, Covid-19 reached Latin America cities. Aim: To report clinical features and outcomes of a group of patients with Covid-19 admitted to a Chilean regional reference Center. Material and Methods: Cases were identified by a compatible clinical picture and a positive PCR or serological test. Clinical features of patients were retrieved from medical records. Results: Forty-seven adult patients (45 diagnosed by PCR, 2 by serology) were admitted between epidemiological weeks 13 to 33, corresponding to $4.4 \%$ of total regional cases. Hospitalization occurred at a median of 10 days after onset of symptoms. Fifty one percent of patients had 60 years or more. Hypertension, obesity and diabetes mellitus were present in 57,45 and $32 \%$ of cases, respectively. Nineteen percent of patients had no comorbid condition nor were elderly. Two cases were women in their second trimester of pregnancy. Positive IgM or IgM/ IgG results obtained by rapid serological testing, had limited sensitivity during the first week (67\%). Seventeen patients (36.2\%) were transferred to an intensive care unit (ICU) due to respiratory failure. Chest imaging demonstrated a classical COVID-19 pattern in 87\%. By univariate analysis, admission to ICU was significantly associated with tachypnea and higher CALL (comorbidity, age, lymphocyte count and lactate dehydrogenase) score. Four patients died (rendering a hospital mortality of $8.5 \%$ ) and length of stay was $\geq 14$ days in $46.8 \%$ of patients. By univariate analysis, mortality was associated with immunosuppression and ICU admission. Conclusions: In our regional Center, patients admitted with COVID-19 had usual risk factors and had a prolonged stay. Hospital mortality was associated with immunosuppression and ICU admission.
\end{abstract}

(Rev Med Chile 2020; 148: 1577-1588)

Key words: COVID-19; Critical Care; Pneumonia; Real-Time Polymerase Chain Reaction; Serologic Tests.

\section{Características clínicas de 47 pacientes con COVID-19 ingresados a un centro regional en Chile}

Antecedentes: Durante la primera ola pandémica, COVID-19 llegó a las ciudades de América Latina. Objetivos: Informar las características clínicas y
'SubDepartamento de Medicina, Hospital Base de Valdivia.

Valdivia, Chile.

${ }^{2}$ Servicio de Farmacia, Hospital Base de Valdivia. Valdivia, Chile. ${ }^{3}$ Instituto de Farmacia, Facultad de Ciencias, Campus Isla Teja, Universidad Austral de Chile. Valdivia, Chile.

${ }^{4}$ Instituto de Medicina, Facultad de Medicina, Campus Isla Teja, Universidad Austral de Chile. Valdivia, Chile.

${ }^{5}$ Carrera de Química y Farmacia, Facultad de Ciencias, Campus Isla Teja, Universidad Austral de Chile. Valdivia, Chile.

${ }^{6}$ Laboratorio de Virología, Instituto de Microbiología Clínica, Facultad de Medicina, Universidad Austral de Chile. Valdivia, Chile.

${ }^{7}$ Laboratorio de Biología Molecular, Hospital Base de Valdivia. Valdivia, Chile.

${ }^{8}$ Servicio Laboratorio Clínico, Hospital Base de Valdivia.

Valdivia, Chile.

${ }^{9}$ SubDepartamento de Imagenología, Hospital Base de Valdivia. Valdivia, Chile.

${ }^{10}$ Unidad de Pacientes Críticos, Hospital Base de Valdivia. Valdivia, Chile.

Conflicto de Interés: ninguno. Financiamiento: ninguno.

Recibido el 9 de junio de 2020, aceptado el 10 de noviembre de 2020 .

Correspondencia a: Dr. Alberto Fica Cubillos Médico Infectólogo, SubDepartamento de Medicina, Hospital Base de Valdivia. Bueras 1003, Valdivia, Región De Los Ríos, Chile.

Instituto de Medicina, Facultad de Medicina, Campus Isla Teja, Universidad Austral de Chile, Valdivia, Chile. albertoficacubillos@gmail.com 
los resultados asociados a COVID-19 en un grupo de pacientes ingresados en un Centro de referencia regional en el sur de Chile. Material y Métodos: Los casos fueron identificados por un cuadro clínico compatible asociado a RT-PCR positiva o prueba serológica. La información clínica de los pacientes se obtuvo de sus fichas. Resultados: Entre las semanas epidemiológicas 13 y 33 ingresaron 47 pacientes adultos (45 diagnosticados por PCR, 2 por serología), lo que representa el 4,4\% del total de casos regionales. La hospitalización se produjo con una mediana de 10 días después del inicio de los sintomas. El 51\% de los pacientes tenía 60 años o más. La hipertensión arterial (57,4\%), la obesidad (44,7\%) y la diabetes mellitus 2 (31,9\%) fueron prevalentes, pero el $19 \%$ no presentaba comorbilidades ni era un adulto mayor. Dos casos ocurrieron en mujeres embarazadas en el segundo trimestre. Los resultados positivos de IgM o IgM / IgG obtenidos mediante pruebas serológicas rápidas tuvieron una sensibilidad limitada durante la primera semana (66,7\%). Diecisiete pacientes (36,2\%, grupo crítico) fueron trasladados a UCI por insuficiencia respiratoria. Las imágenes de tórax demostraron un patrón COVID-19 clásico en el 87\% de los casos. Por análisis univariado, el ingreso en UCI se asoció significativamente con taquipnea y puntuaciones CALL (comorbidity, age, lymphocyte count and lactate dehydrogenase) elevadas. Cuatro pacientes fallecieron (mortalidad hospitalaria 8,5\%) y la estadía hospitalaria fue $\geq 14$ días en el $47 \%$ de los pacientes. Por análisis univariado la mortalidad se asoció a inmunodepresión y al ingreso a UCI. Conclusiones: En nuestro Centro regional, COVID-19 se asoció a factores de riesgo conocidos y tuvo una estadía prolongada. La mortalidad hospitalaria se asoció con inmunosupresión o ingreso a UCI.

Palabras clave: COVID-19; Neumonía; Cuidados Críticos; Pruebas Serológicas; Reacción en Cadena.

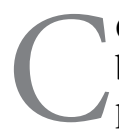

OVID-19 is an emerging disease caused by the SARS-CoV-2 virus and first reported in late 2019 in China $^{1}$. Due to its rapid expansion, on March 2020 it was declared a global pandemic by the $\mathrm{WHO}^{2}$ and up to date has affected more than 32.7 million worldwide of whom 991,000 have died ${ }^{3}$. The first case reported in Chile was registered on March $3^{\text {rd }}$ and at the end of September over 500,000 cases has been notified with 16,000 deceased ${ }^{4}$. Currently there is little information on the clinical presentation of COVID-19 and its outcomes in Latin America, especially in hospitalized patients $s^{5-8}$. This could contrast with that reported in countries of the northern hemisphere, which have different features on demographic, economic, cultural, healthcare systems and/or mitigation strategies $^{9-15}$. We present this preliminary report on a cohort of COVID-19 patients during the first wave in a southern region in Chile focusing on clinical features and outcomes in a reference center.

\section{Patients and Methods}

\section{Study design, inclusion criteria and laboratory tests}

Retrospective descriptive study of patients admitted during the first wave at the Hospital Regional of Valdivia, in Southern Chile. Patients were included, if had suspicious symptoms plus either a positive SARS-CoV-2 RT-PCR or a rapid serological test coupled with compatible chestCT imaging. For RT-PCR tests, nasopharyngeal swab samples were obtained and placed in viral transport medium. Total nucleic acids were extracted from $200 \mu \mathrm{L}$ of transport medium with Chemagic Prepito Instrument using Prepito Viral DNA/RNA Kit (both PerkinElmer ${ }^{\mathrm{TM}}$ ) according to manufacturer's recommendations and eluted in $100 \mu \mathrm{L}$ of an elution buffer. SARS-CoV-2 RNA was detected using the Primer design COVID-19 Genesig Real-Time PCR assay and the amplification reaction was performed in a Bio-Rad ${ }^{\circledR}$ CFX96 thermocycler according to 
manufacturer's instructions. Specimens were considered positive if the $\mathrm{Ct}$ value was $<37$ and internal controls were detected. In parallel, the quality of the samples was checked with a human RNAse P Real-Time PCR assay with the CDC primers from IDT. Serology was performed using the "VivaDiag COVID-19 IgM / IgG Rapid Test lateral flow immunoassay (LFIA)" kit based on the addition of $10 \mu \mathrm{L}$ of serum and then 2 to 3 drops of $(70-100 \mu \mathrm{L})$ buffer dilution. Results were read after 15 minutes.

\section{Regional management protocol}

Los Ríos Region has an estimated population of 406,000 inhabitants ${ }^{16}$. Most of the population $(>80 \%)$ is cared for in an integrated network of primary care centers and low-complexity hospitals, with only one high-complexity reference center (Hospital Regional) designated to receive severe and critically ill COVID-19 patients. Severity illness stratification was performed based on a regional clinical care guideline using the following classification: a) Mild: no need of oxygen therapy or hospitalization; b) Moderate: low oxygen requirement $\left(\mathrm{FiO}_{2}<32 \%\right) ; \mathrm{PaO}_{2} / \mathrm{FiO}_{2}$ ratio $\geq 200$, respiratory rate $<30 / \mathrm{min}$, and no shock or organ dysfunction; c) Severe: $\mathrm{FiO}_{2} 32-40 \% ; \mathrm{PaO}_{2} / \mathrm{FiO}_{2}$ ratio $\geq 200$, respiratory rate $\geq 30 / \mathrm{min}$, without shock or organ dysfunction, and d) Critical: $\mathrm{FiO}_{2}$ $>40 \% ; \mathrm{PaO}_{2} / \mathrm{FiO}_{2}$ ratio $<200$, septic shock, organ dysfunction, chest $\mathrm{x}$-ray with bilateral infiltrates and / or requirement for invasive mechanical ventilation (IMV). Patients in severe or critical conditions were transferred to the Regional Hospital. The guideline considered the use of hydroxychloroquine (HQ; day 1: $400 \mathrm{mg}$ every $12 \mathrm{~h}$, day 2-5: $200 \mathrm{mg}$ every $12 \mathrm{~h}$ ) in all admitted patients as well as those $>60$ years and/or with chronic diseases until epidemiological week (EW) 20. All admitted patients received a beta-lactam antibiotic and pharmacological prophylaxis for thromboembolic disease. Besides, critical patients with a $\mathrm{D}$-dimer $(\mathrm{DD})$ value $>6$ times the normal value were prescribed with an intermediate heparin dose (unfractionated formulation 5,000 UI q8 hours or enoxaparin $1 \mathrm{mg} / \mathrm{kg} /$ day). The use of glucocorticoids and convalescent plasma were indicated according to the criteria of physicians in charge. However, universal treatment with dexamethasone $6 \mathrm{mg} / \mathrm{d}$ was applied to all patients with $\mathrm{O}_{2}$ requirement after EW 25 .

\section{Clinical characterization and outcomes}

Demographic, epidemiological and clinical variables were retrieved from medical records. The CALL score was calculated as described ${ }^{17}$ as well SOFA and APACHE II in those admitted to the ICU. Pharmacological therapies, complications, clinical outcomes, length of stay and in-hospital mortality were extracted and calculated from medical records. Chest imaging was classified according to the British Society of Thoracic Imaging as a classical (bilateral foci of ground-glass opacities mainly located at peripheral areas and at lower lobes) or indeterminate pattern (findings that do not match with a classical or a not-COVID-19 pattern $)^{18,19}$. Images were also classified for quantifying disease.

\section{Statistical analysis and ethical issues}

Data corresponding to quantitative variables is presented as medians with interquartile range (IQR) and categorical variables as percentages. Analysis of potential factors associated with ICU admission or death was calculated by odds ratios. This work was approved by the Comité de Ética Científico of Servicio de Salud Valdivia.

\section{Results}

\section{Cases identified and epidemiological features}

Forty-seven patients with severe or critical COVID-19 disease (2 diagnosed by clinical features and positive serology) were admitted to our hospital between epidemiological weeks 13 and 33 , a group that compose this preliminary report. During this timeframe, hospital admissions at our center (all in severe or critical condition) represented $4.4 \%$ of total reported cases in the region (47 out of 1076). Figure 1 shows the impact of the first wave on admissions at our reference center.

\section{Clinical features}

Median age was 60 years (IQR 49-69 years) and half were $\geq 60$ years old (Table 1). Gender distribution was balanced and contact with a known Covid-19 case was frequent. A healthcare worker integrates this report whose contagion occurred in a primary care center. Hypertension, obesity, and type 2 diabetes mellitus were prevalent (Table 1). Two patients were pregnant and $19 \%$ had no comorbid history. The use of active drugs on the 


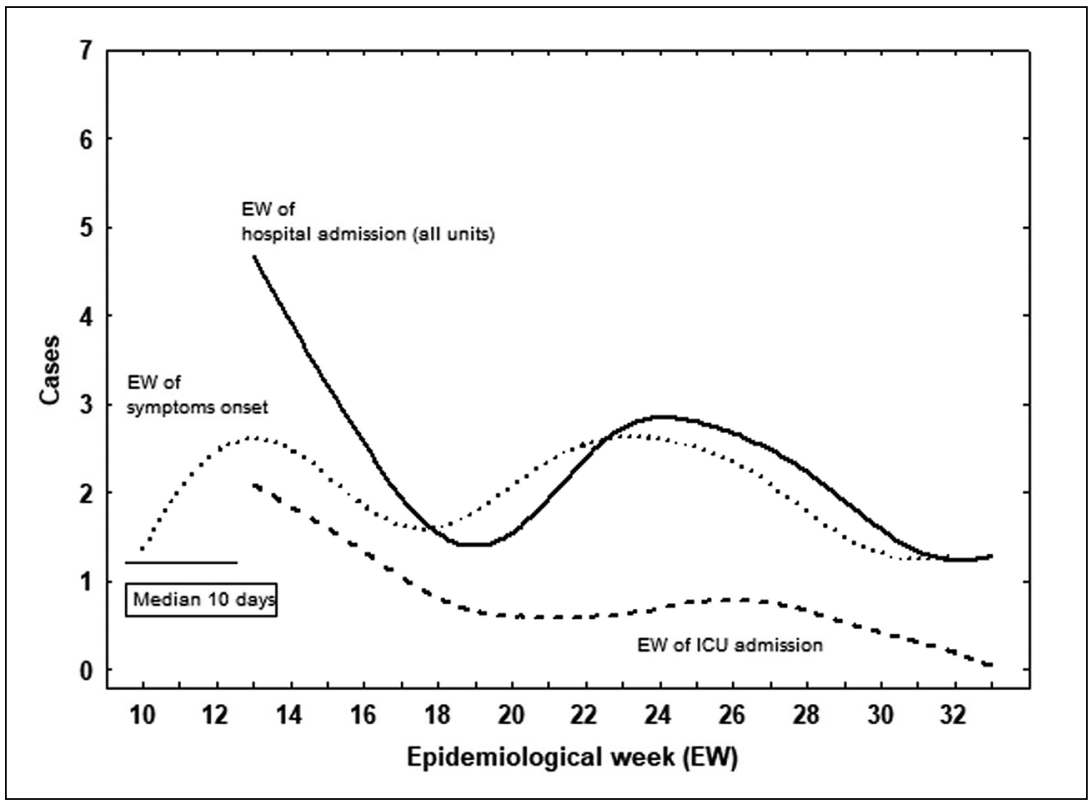

Figure 1. Distribution of cases with COVID-19 admitted to the hospital according to epidemiological week (EW) from symptoms onset. More than a week of delay between symptoms onset and admission is observed. Curves were fitted by the least square method.
Table 1. Features of 47 patients admitted with COVID-19 to Hospital Base de Valdivia during the first pandemic wave 2020

\begin{tabular}{|c|c|}
\hline Variable & Results \\
\hline Age in years mean (range) & $61(26-85)$ \\
\hline Age $\geq 60$ years old $n(\%)$ & $24(51.1 \%)$ \\
\hline Female n (\%) & $22(46.8 \%)$ \\
\hline $\begin{array}{l}\text { Contact with a known Covid-19 case } n \\
(\%)\end{array}$ & $32(68.1 \%)$ \\
\hline Healthcare worker n (\%) & $1(2.1 \%)$ \\
\hline Previous/current tobacco smoking n (\%) & $2(4.3 \%)$ \\
\hline $\begin{array}{l}\text { Use of renin-angiotensin-aldosterone } \\
\text { system inhibitors } n(\%)\end{array}$ & $16(34.0 \%)$ \\
\hline 2020 influenza vaccine $\mathrm{n}(\%)$ & $22(46.8 \%)$ \\
\hline \multicolumn{2}{|l|}{ Comorbid conditions/pregnancy $n(\%)$} \\
\hline Hypertension & $27(57.4 \%)$ \\
\hline Obesity & $21(44.7 \%)$ \\
\hline Diabetes Mellitus type 2 & $15(31.9 \%)$ \\
\hline Asthma/COPD/lung fibrosis & $9(19.1 \%)$ \\
\hline Chronic kidney disease & 2 (4.3\%) \\
\hline Heart disease & 4 (8.5\%) \\
\hline Chronic liver disease & 1 (2.1\%) \\
\hline Immunosuppression & $3(6.4 \%)$ \\
\hline Age $<60$ without comorb & $9(19.1 \%)$ \\
\hline Pregnancy & $2(4.3 \%)^{*}$ \\
\hline
\end{tabular}

*Both with a second trimester pregnancy. renin-angiotensin-aldosterone system approached $35 \%$ of the series (Table 1). Predominant symptoms in order of frequency were cough, fever and myalgia. This triad was followed by dyspnea and rhinorrhea and then by odynophagia, dysgeusia, diarrhea and anosmia (Figure 2). Hypotension on admission was infrequent (6.4\%). Median symptomatic period before admission was 10 days (IQR 6-13 days, Figure 1). About half of our patients were admitted with tachypnea and an abnormal $\mathrm{PaO}_{2} / \mathrm{FiO}_{2}$ ratio but low $\mathrm{O}_{2}$ saturation on pulse oximetry or hypoxemia in arterial gases was infrequent (Table 2). We rarely observed patients with leukocytosis, neutrophilia or marked thrombocytopenia. In contrast, patients with lymphopenia $(38.3 \%)$ were frequent. The series also highlights the high frequency of patients with elevated LDH and ferritin plasmatic values (>70\%, Table 2$)$. Coagulation parameters (International Normalized Ratio and activated partial thromboplastin time) did not show major alterations, but DD values were elevated in $40 \%$ of patients.

\section{Management, complications, and outcome}

Approximately a third of patients were transferred to ICU (Table 3), all requiring IMV with median SOFA and APACHE II scores of 3 points (range 2-9) and 12 points (range 3-31), 


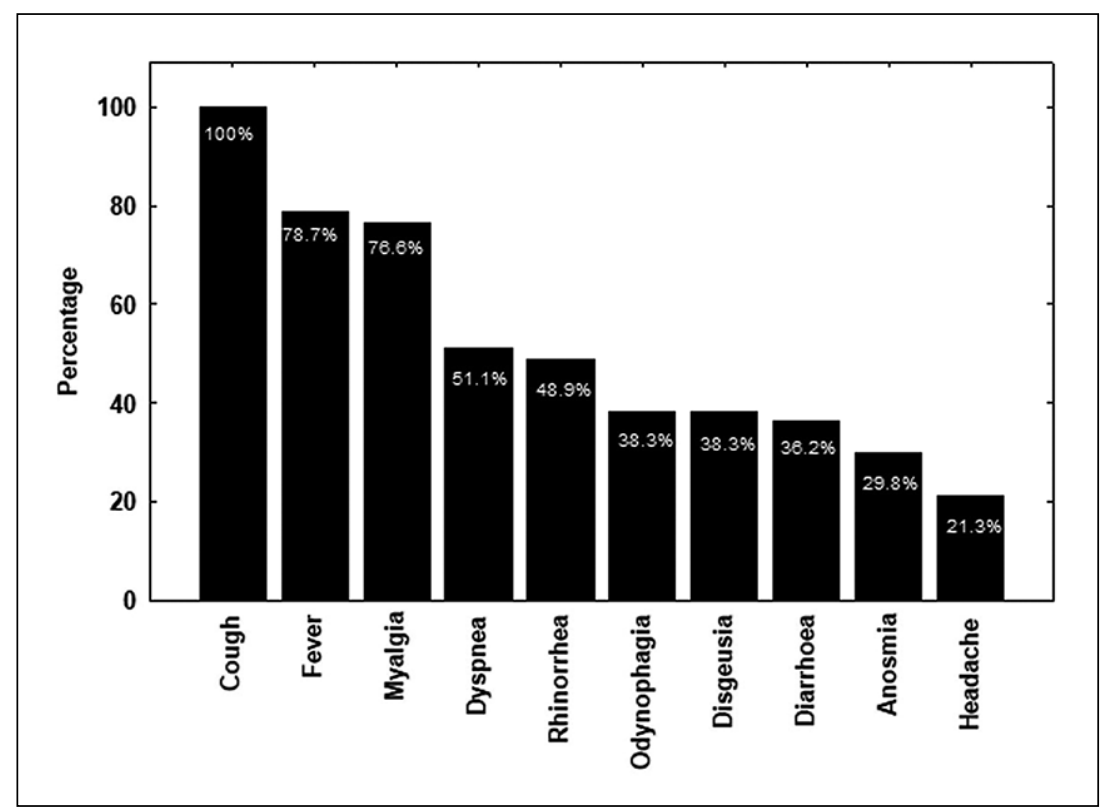

Figure 2. Distribution of symptoms among 47 admitted patients to a Regional Reference Center for severe and critical COVID-19 cases in Valdivia, Southern Chile. respectively. Half had a CALL score in the highest severity range (10-13 points, Table 3$)$. The use of vasoactive drugs was required in 16 out of 17 patients with IMV. HQ, either alone or coupled with lopinavir/ritonavir was indicated until EW 18 but not thereafter. Conversely, dexamethasone was prescribed progressively since EW 25 but not before except in one case of thrombocytopenic purpura (data not shown). We separated cases when corticosteroids were early indicated (during the $1^{\text {st }}$ week of symptoms and for at least 3 days) and found that $<40 \%$ did receive them so (Table 3). Compounds different to dexamethasone were indicated in patients with refractory ARDS (methyl prednisolone), refractory shock (hydrocortisone), obstructive bronchitis (hydrocortisone) or to achieve fetal maturation (betamethasone). In the latter case, she had a 28 weeks pregnancy and underwent an urgent cesarean section. She had a premature newborn weighing 1540 grams, with hypotonia, intraventricular hemorrhage, seizures, neonatal jaundice and later bacteremia requiring IVM connection and application of pulmonary surfactant. Perinatal transmission of SARS-CoV-2 was ruled out.

Among observed complications, acute respiratory distress syndrome (ARDS) was recorded in 18 patients $(38.3 \%)$, nosocomial infections in $23.4 \%$, and acute kidney injury in $17 \%$ (with dialysis requirement in one of them). A prolonged QTc interval event was registered in 2 patients but without arrhythmia (Table 3). Health care-associated infections included 3 events of bloodstream infections, 2 of ventilator-associated pneumonia, 2 of urinary tract infection, one case of fever without an identified source, one event of Clostridoides difficile diarrhea and one patient with multiple nosocomial infections. Median hospital stay was 11 days with near half remaining hospitalized $\geq 2$ weeks. However, a significant decrease of length of stay (LOS) was observed during the study period (Spearman correlation coefficient -0.37; $\mathrm{p}=0.001$, Figure 3). Median LOS until EW 20 was 21.5 (IQR 11-29) days versus 10 days (IQR 7-17) after EW 20. Four of our patients died (in-hospital mortality $8.5 \% ; 23.5 \%$ of those admitted to ICU) due to central venous catheter-associated bloodstream infection (one case), refractory ARDS (2 cases) and early respiratory failure (one case).

\section{Serological and molecular studies}

All but 2 patients underwent a rapid serologic test to detect IgM/IgG antibodies. Sensitivity of this rapid test was $66.7 \%$ at the first week of symptoms, increased to $88.3 \%$ (second week) and to $100 \%$ thereafter (Figure 4 ). 
Table 2. Physical and laboratory parameters at admission among 47 patients admitted with COVID-19 to Hospital Base de Valdivia during the first pandemic wave

\begin{tabular}{|c|c|}
\hline Parameter & Results \\
\hline Temperature (Celsius) & $37.1(36.5-37.9)$ \\
\hline Fever n (\%) & $37(78.7 \%)$ \\
\hline Respiratory rate per minute & $30(26-34)$ \\
\hline Tachypnea ( $\geq 30 / \min$ ) n (\%) & $24(51.1 \%)$ \\
\hline Heart rate (beats/min) & $92(81-106)$ \\
\hline $\mathrm{O}_{2}$ pulse digital oximetry (\%) & $92(90-95)$ \\
\hline $\mathrm{O}_{2}$ Saturation < 90\% n (\%) & $11(23.4 \%)$ \\
\hline $\mathrm{PaO}_{2}$ at admission $\mathrm{mmHg}$ & $80.7(70-102.5)$ \\
\hline $\mathrm{PaO}_{2}<60 \mathrm{mmHg}$ & $2(4.3 \%)$ \\
\hline $\mathrm{PaFiO}_{2}$ & $278(213-363)$ \\
\hline $\mathrm{PaFiO}_{2}<300$ n (\%) & $29(61.7 \%)$ \\
\hline Blood leucocyte count/ $\mu \mathrm{L}$ & $6,870(5,940-8,960)$ \\
\hline Leukocytosis $>15,000 / \mu \mathrm{L}$ & $1(2.1 \%)$ \\
\hline Blood polymorphonuclear count/ $\mu \mathrm{L}$ & $5,400(4,300-6,800)$ \\
\hline Neutrophilia $>12,000 / \mu \mathrm{L}$ & $1(2.1 \%)$ \\
\hline Lymphocyte count / $\mu \mathrm{L}$ & $1,200(900-1,500)$ \\
\hline Lymphocyte count $\leq 1,000 / \mu \mathrm{L}$ n (\%) & $18(38.3 \%)$ \\
\hline Platelet count $/ \mu \mathrm{L}$ & $209,000(158,000-290,000)$ \\
\hline Thrombocytopenia < 100,000 / $\mu \mathrm{L}$ median $\mathrm{n}(\%)$ & $4(8.5 \%)$ \\
\hline $\mathrm{LDH}$ in plasma $\mathrm{U} / \mathrm{L}^{*}$ & $332(253-432)$ \\
\hline$\leq 250 \mathrm{U} / \mathrm{L}$ (normal range) & $9(20 \%)$ \\
\hline $251-500 \mathrm{U} / \mathrm{L}$ & $32(71.1 \%)$ \\
\hline$>500 / \mathrm{UL}$ & $4(8.9 \%)$ \\
\hline Blood urea nitrogen $(\mathrm{mg} / \mathrm{dL})$ & $14(10-21)$ \\
\hline C-reactive protein (mg/L) & $9,6(7,1-14,8)$ \\
\hline International Normalized Ratio & $1.12(1.07-1.17)$ \\
\hline Activated partial thromboplastin time (sec) & $34.4(29-39.8)$ \\
\hline D-dimer $\mu \mathrm{g} / \mathrm{mL}^{*}$ & $0,4(0,2-0,9)$ \\
\hline D-dimer over normal value (>0.5 $\mu \mathrm{g} / \mathrm{mL})$ & $18(40 \%)$ \\
\hline Plasma ferritin $\mathrm{ng} / \mathrm{mL}^{*}$ & $829(304-1,579)$ \\
\hline Over normal value (> 150 ng/mL) & $40(88.9 \%)$ \\
\hline$>800 \mathrm{ng} / \mathrm{mL}$ & $25(55.6 \%)$ \\
\hline
\end{tabular}

Data are shown as median (interquartile 25,75 range). *of patients with available results.

\section{Thoracic imaging}

Images were analyzed using chest $\mathrm{x}$-rays $(\mathrm{n}=42 ; 89.4 \%)$ or CT images $(\mathrm{n}=5 ; 10.4 \%)$. The classical pattern predominated $(\mathrm{n}=41$; $87.2 \%)$ over the indeterminate type $(n=6$; $12.8 \%$ ) (Figure 5). Disease severity was scored by imaging as mild (31.9\%), moderate (55.3\%) or severe $(12.8 \%)$. Time elapsed between symptoms onset and imaging date ( $>$ or $\leq 1$ week) did not change appreciably the detection of a classical pattern $(90.3 \%$ vs. $81.3 \%)$. However, severe disease by imaging was only detected in patients with $>1$ week of symptoms onset (trend; $\mathrm{p}=0.08$ ). 
Table 3. CALL score, management, complications and outcomes among 47 patients admitted with Covid 19 to the Hospital Base de Valdivia during the first pandemic wave

\begin{tabular}{|c|c|}
\hline Variable & Results \\
\hline \multicolumn{2}{|l|}{ CALL score $n(\%)^{*}$} \\
\hline 4-6 points & $7(15.2 \%)$ \\
\hline 7-9 points & $14(30.4 \%)$ \\
\hline $10-13$ points & $25(52.4 \%)$ \\
\hline \multicolumn{2}{|l|}{ Place of hospitalization $n(\%)$} \\
\hline General ward & $30(63.8 \%)$ \\
\hline Critical Care Unit & $17(36.2 \%)$ \\
\hline \multicolumn{2}{|l|}{ Ventilatory support n (\%) } \\
\hline Invasive mechanical ventilation & $17(36.2 \%)$ \\
\hline Prone position & $13(27.7 \%)$ \\
\hline Non-invasive mechanical ventilation only & $0 \quad(0 \%)$ \\
\hline High-flow nasal cannula & $15(31.9 \%)$ \\
\hline Vaso-active drugs & $16(34.0 \%)$ \\
\hline \multicolumn{2}{|l|}{ Drug Treatment n (\%) } \\
\hline Hydroxychloroquine & $9(19.1 \%)$ \\
\hline Hydroxychloroquine + lopinavir/ritonavir & $7(14.9 \%)$ \\
\hline Macrolides & $13(27.7 \%)$ \\
\hline High-intermediate doses of low-molecular weight heparin & $13(27.7 \%)$ \\
\hline Corticosteroids (any) & $26(55.3 \%)$ \\
\hline Dexamethasone & $18(34.0 \%)$ \\
\hline Appropriate opportunity ( $\leq 7$ days from symptoms onset and for at least 3 days) & $18(38.3 \%)$ \\
\hline Convalescent plasma administration & $22(46.8 \%)$ \\
\hline Cesarean section & $1(2.1 \%)$ \\
\hline \multicolumn{2}{|l|}{ Complications n (\%) } \\
\hline ARDS & $18(38.3 \%)$ \\
\hline Long QTc interval** & $2(4.3 \%)$ \\
\hline Acute Kidney Injury*** & $8(17.0 \%)$ \\
\hline Hospital-acquired infections & $11(23.4 \%)$ \\
\hline \multicolumn{2}{|l|}{ Hospital length of stay } \\
\hline Median (IQR) in days & $11(8-26)$ \\
\hline$\geq 14$ days $\mathrm{n}(\%)$ & $22(46.8 \%)$ \\
\hline Deceased n (\%) & $4 \quad(8.5 \%)$ \\
\hline
\end{tabular}

*in patients with available results; ${ }^{* *}$ no associated arrhythmia; ${ }^{* * *}$ one case with dialysis requirement.

Comparison of critical versus non-critical group An exploratory analysis was performed to identify possible factors associated to ICU admission and in-hospital mortality. On univariate analysis, requirement of admission to ICU was significantly associated with tachypnea (OR 5.61; IC95 1.46-21.5; $\mathrm{p}=0.015$ ) or a higher CALL score
(> 9; OR 4.33; IC95 1.12-16.6; $\mathrm{p}=0.035)$ but not to other clinical variables or comorbidities. On the other hand, in-hospital mortality was significantly associated to immunosuppression (OR 42; IC95 $2.58-682 ; \mathrm{p}=0.016$ ) or to ICU admission (OR 20.3; IC95 1.02-404; $\mathrm{p}=0.013$ ) but not to other explored variables. 

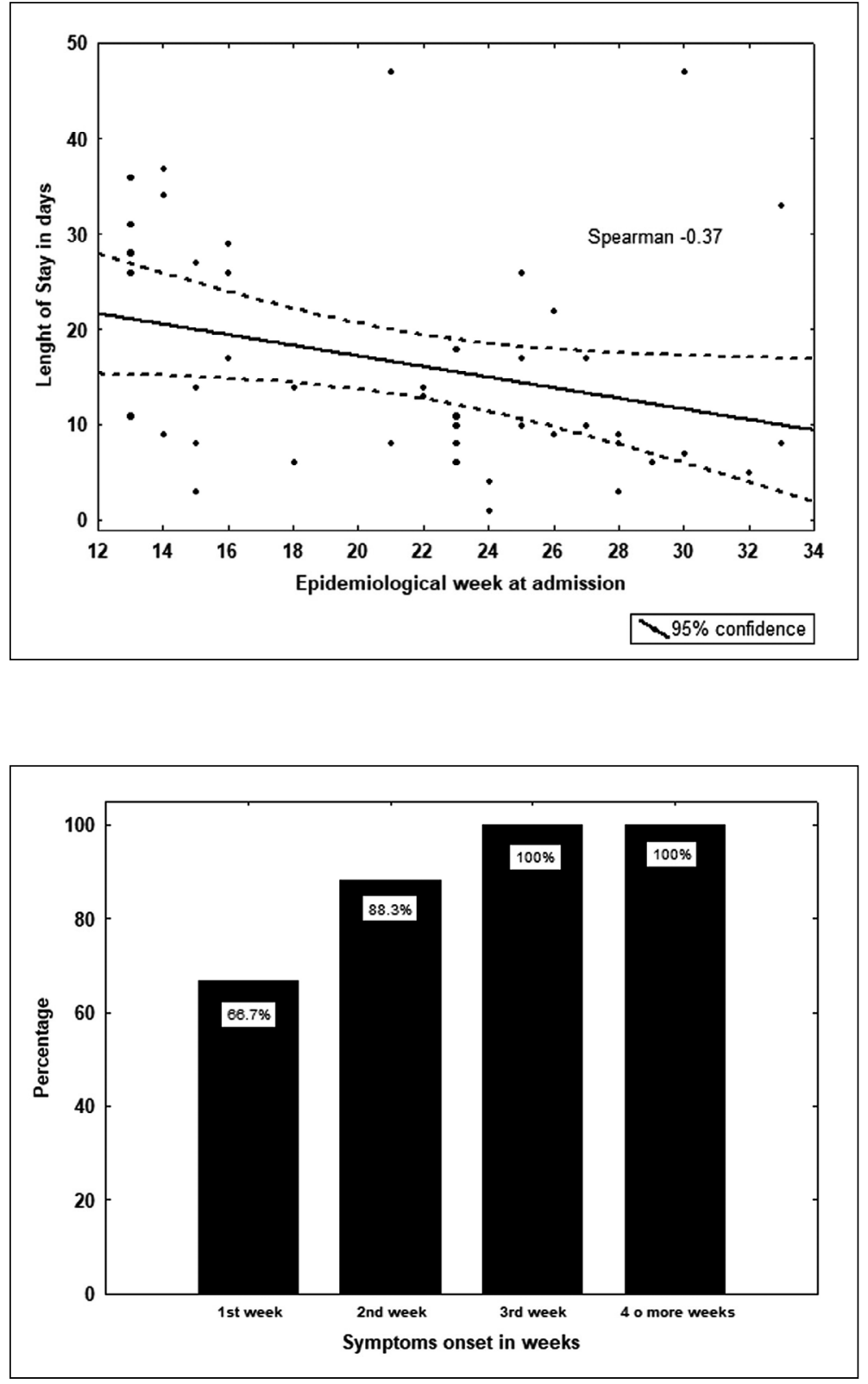

Figure 3. Fitted linear regression curve of length of stay (LOS) according to epidemiological week (EW) of admission. Dotted boundaries indicate IC95 interval. LOS after EW 20 was lower than LOS before that cutoff (Mann Whitney test, $p=0.001)$. The Spearman correlation test was also significant $(p<0.05)$.

\section{Discussion}

Information on clinical features, management, and outcome for this infection in our region is crucial to compare if hospital resources demand and disease outcomes are comparable to those reported by other developed or developing countries and to evaluate the impact of changing therapies during the first months of COVID-19 pandemic. In our center, patients were managed using a protocol built according to the best evidence available at the time of its preparation ${ }^{20-22}$ and although pharmacological therapies such as lopinavir, ritonavir and HQ were initially considered, they were ultimately questioned or disregarded ${ }^{23-27}$. The existence of local guidelines made it possible to 

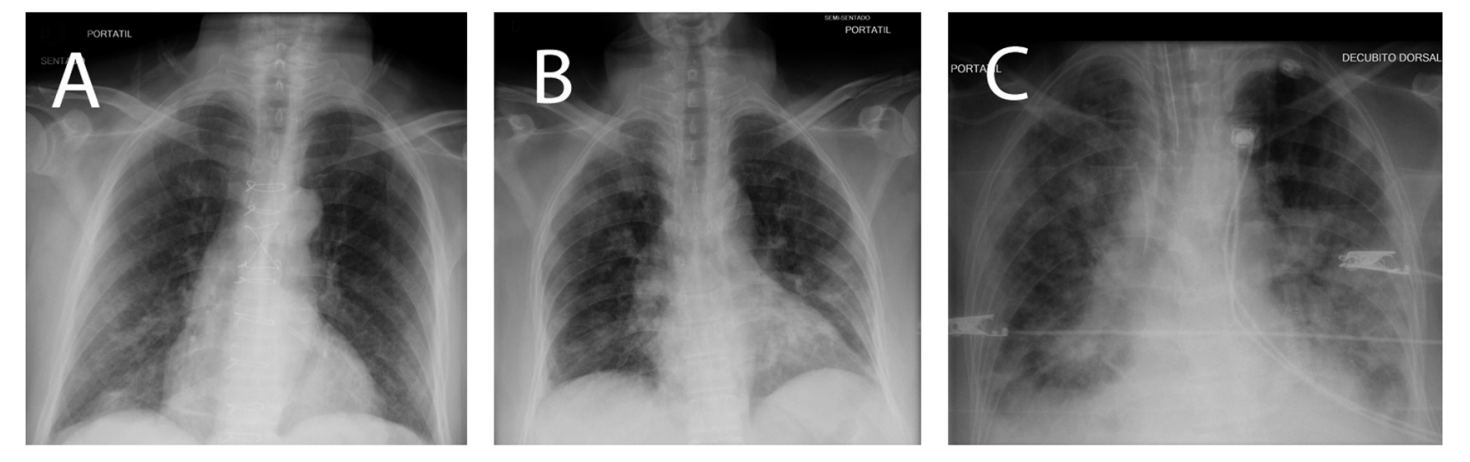

Figure 5. A. Chest $x$-ray with an indeterminate pattern (not displaying classical finding nor features associated with other diseases); B. Chest x-ray showing multiple ground glass opacities that are predominating at peripheral sites at in lower lobes (classical pattern). The image was taken at 11 days from symptoms onset; $\mathbf{C}$. Same patient as before with progression of chest infiltrates and connection to invasive mechanical ventilation (taken at 18 days of evolution).

work in a uniform manner in the whole Southern area of Chile.

As in other experiences, we were able to confirm that hospital admissions occur several days after the onset of symptoms, that less than $10 \%$ of all cases require hospitalization and that hospital stay was prolonged ${ }^{9,14}$. Patient characteristics reflected the weight of comorbidities and advanced age, occasional involvement of healthcare personnel or pregnant women, and known systemic and respiratory symptoms in addition to changes in taste or smell or gastrointestinal manifestations. In our series, ICU admission was high (about $50 \%$ of admissions) because our hospital served as a reference center. All patients received initially HQ per protocol, a drug whose efficacy and safety has been questioned ${ }^{23,24}$. Furthermore, two cases of QTc prolongation were observed but none presented arrhythmias.

At the beginning, steroid therapy was applied on a case-by-case basis but not by protocol since there was no consensus regarding its use. Although available evidence was initially not consistent ${ }^{28,29}$, early experiences suggested that administration could increase survival ${ }^{30,31}$. Its use in turn, must be balanced with its known association with infectious complications, myopathy, delirium, hyperglycemia, gastrointestinal bleeding, or hydro-electrolyte disorders ${ }^{32}$. Corticosteroids in ARDS secondary to other viral etiologies have been associated with a delayed viral clearance ${ }^{33}$ or even increased mortality ${ }^{29,34}$. Results of a ran- domized clinical trial and a systematic review on the benefit of corticosteroids on COVID-19 have been published and have demonstrated a favorable impact on morbidity and mortality but restricted to patients with $\mathrm{O}_{2}$ requirement or ICU admission and mainly linked to dexamethasone ${ }^{35,36}$. Consequently, we adapted our local guideline and started with dexamethasone therapy after EW 25. In our data, a beneficial effect of dexamethasone could not be detected probably due to the small size of our series.

There were 2 patients carrying a second trimester pregnancy who presented with pneumonia and respiratory failure due to SARS-CoV-2, one of them with severe illness that responded to conventional $\mathrm{O}_{2}$ therapy without fetal or maternal complications. The second evolved in a critical condition, requiring IMV and prompt fetal lung maturation with corticosteroids. Her clinical course was favorable after an urgent cesarean section and convalescent plasma therapy. The impact of this infection in pregnancy is beginning to be delineated with rare intrauterine transmission events and low maternal mortality ${ }^{37}$. Fetal consequences may include intrauterine growth retardation, cyanosis, gastrointestinal bleeding, and neonatal mortality ${ }^{37}$.

Convalescent plasma is a potentially beneficial therapy $^{38,39}$ with an adequate safety profile ${ }^{40}$. A randomized clinical trial reported a trend towards a better clinical improvement (28 days) and lower mortality ${ }^{41}$. However, its benefit has 
not been yet proved and high percentages of patients had already neutralizing titers against SARS-CoV-2 before receiving convalescent plasma $^{42}$.

Laboratory tests showed an inflammatory state and procoagulant status. The relevance of tachypnea and the CALL score in the identification of critically ill patients requiring ICU admission was confirmed ${ }^{17}$. On the other hand, immunosuppression, and ICU admission (a proxy of ARDS or IMV) were significantly associated to in-hospital mortality as previously reported ${ }^{43-45}$. The low number of patients in this observational study avoided recognize if other variables such as an advanced age, chronic diseases, coagulopathy, increased D-dimer, troponin or ferritin levels, neutrophilia, lymphopenia, and/or leukocytosis were associated with severity or an adverse outcome $e^{46-49}$.

Serology by a rapid commercial antibody-based test was performed in all patients with $66.7 \%$ sensitivity in the first week of symptoms similar to other experiences ${ }^{50,51}$ underlying its limited utility for early diagnosis. However, it can be helpful when a high suspicion exists despite serial negative RT-PCT and compatible symptoms and chest images as happened in some of our patients. Thoracic images can be very suggestive of SARSCoV-2 infection in what is described as a classical pattern ${ }^{18,19}$. In our experience, most patients presented these features even during the first week of evolution, but they were not associated with prognosis.

Complications observed underline the high frequency of ARDS and healthcare associated infections ${ }^{52}$. Autopsy studies have revealed the presence of diffuse alveolar damage, in exudative and proliferative phases, including alterations such as capillary congestion, pneumocyte necrosis, hyaline membrane, interstitial edema, atypical and hyperplastic pneumocytes, and microthrombi in arterioles $^{53,54}$. These findings support the use of anticoagulants in patients with high $\mathrm{DD}^{55}$, which in observational studies has shown to reduce mortality ${ }^{56,57}$. Thus, all our patients received heparin prophylaxis and in one third we used high to intermediate doses due to high DD values.

In conclusion, in our regional reference hospital, COVID-19 incidence was associated to known risk factors, had a prolonged stay and immunosuppression or ICU admission were related to hospital mortality.

\section{References}

1. Wu Z, McGoogan JM. Characteristics of and Important Lessons From the Coronavirus Disease 2019 (COVID-19) Outbreak in China: Summary of a Report of 72314 Cases From the Chinese Center for Disease Control and Prevention. JAMA 2020; 323 (13): 1239-42.

2. Cucinotta D, Vanelli M. WHO declares COVID-19 a pandemic. Acta Biomed 2020; 91 (1): 157-60.

3. World Health Organization. Weekly epidemiological update. Coronavirus disease 2019 (COVID-2019). 28 september 2020. Disponible en: https:// www.who.int/docs/default-source/coronaviruse/ situation-reports/20200928-weekly-epi-update.pdf?sfvrs$\mathrm{n}=9 \mathrm{e} 354665 \_2$ [consultado el 28 de septiembre de 2020].

4. Departamento de Epidemiología, MINSAL, Chile. Informe epidemiológico No 54. Enfermedad por SARSCoV-2 (COVID-19) Chile 25-09-2020. Disponible en: https://www.minsal.cl/wp-content/uploads/2020/09/ Informe-Epidemiologico-54.pdf

5. de Souza W, Buss L, Da D, Carrera J, Li S, Zarebski A, et al. Epidemiological and clinical characteristics of the COVID-19 epidemic in Brazil. Nat Hum Behav 2020; 4 (8): 856-65.

6. Escalera-Antezana JP, Lizon-Ferrufino NF, Maldonado-Alanoca A, Alarcon-De-la-Vega G, Alvarado-Arnez LE, Balderrama-Saavedra MA, et al. Risk factors for mortality in patients with Coronavirus Disease 2019 (COVID-19) in Bolivia: An analysis of the first 107 confirmed cases. Infez Med 2020; 28 (2): 238-42.

7. Kammar-García A, Vidal-Mayo JJ, Vera-Zertuche JM, Lazcano-Hernández M, Vera-López O, Segura-Badilla $\mathrm{O}$, et al. Impact of comorbidities in Mexican SARS-CoV-2-positive patients: a retrospective analysis in a national cohort. Rev Invest Clin 2020; 72 (3): 151-8.

8. Baqui P, Bica I, Marra V, Ercole A, van der Schaar M. Ethnic and regional variations in hospital mortality from COVID-19 in Brazil: a cross-sectional observational study. Lancet Glob Health 2020; 8 (8): e1018-26.

9. Guan W, Ni Z, Hu Y, Liang W, Ou C, He J, et al. Clinical Characteristics of Coronavirus Disease 2019 in China. N Engl J Med 2020; 382: 1708-20.

10. Richardson S, Hirsch JS, Narasimhan M, Crawford J, McGinn T, Davidsonet KW, et al. Presenting characteristics, comorbidities, and outcomes among 5700 patients hospitalized with COVID-19 in the New York City Area. JAMA 2020; 323 (20): 2052-9.

11. Argenziano MG, Bruce SL, Slater CL, Tiao JR, Baldwin MR, Barr RG, et al. Characterization and clinical course of 1000 patients with coronavirus disease 2019 in New York: retrospective case series. BMJ 2020; 369: m1996. 
12. Goyal P, Choi J, Pinheiro L, Schenk E, Chen R, Jabri A, et al. Clinical Characteristics of Covid-19 in New York City. N Engl J Med 2020; NEJMc2010419.

13. Docherty AB, Harrison EM, Green CA, Hardwick HE, Pius R, Norman L, et al. Features of 20133 hospitalised UK patients with covid-19 using the ISARIC WHO clinical characterisation protocol. BMJ 2020; 369: m1985.

14. Casas-Rojo JM, Antón-Santos JM, Millán-Núñez-Cortés JM, Lumbreras-Bermejo C, Ramos-Rincón JM, Roy-Vallejo E, et al. Clinical characteristics of patients hospitalized with COVID-19 in Spain: Results from the SEMI-COVID-19 Registry. Rev Clin Esp 2020; S00142565(20)30206-X.

15. Borobia AM, Carcas AJ, Arnalich F, Alvarez-Sala R, Montserrat J, Quintana M, et al. A cohort of patients with COVID-19 in a major teaching hospital in Europe. J Clin Med 2020; 9 (6): E1733.

16. Instituto Nacional de Estadísticas de Chile. Síntesis de resultados Censo 2017. Disponible en: https://www.censo2017.cl/descargas/home/sintesis-de-resultados-censo2017.pdf [Consultado el 24 de mayo de 2020].

17. Ji D, Zhang D, Xu J, Chen Z, Yang T, Zhao P, et al. Prediction for Progression Risk in Patients with COVID-19 Pneumonia: the CALL Score. Clin Infect Dis 2020; 71 (6): 1393-99.

18. Rodrigues JCL, Hare SS, Edey A, Devaraj A, Jacob J, Johnstone A, et al. An update on COVID-19 for the radiologist - A British society of Thoracic Imaging statement. Clin Radiol 2020; 75 (5): 323-5.

19. Castillo F, Bazaes D, Huete A. Radiología en la Pandemia COVID-19: Uso actual, recomendaciones para la estructuración del informe radiológico y experiencia de nuestro departamento. Rev Chil Radiol 2020; 26 (3): 1-12.

20. Gautret P, Lagier JC, Parola P, Hoang VT, Meddeb L, Mailhe $\mathrm{M}$, et al. Hydroxychloroquine and azithromycin as a treatment of COVID-19: results of an open-label non-randomized clinical trial. Int J Antimicrob Agents 2020; 105949.

21. Yu B, Li C, Chen P, Zhou N, Wang L, Li J, et al. Low dose of hydroxychloroquine reduces fatality of critically ill patients with COVID-19. Sci China Life Sci 2020; 15: $1-7$.

22. Yao TT, Qian JD, ZhuWY,Wang Y,Wang GQ. A systematic review of lopinavir therapy for SARS coronavirus and MERS coronavirus-A possible reference for coronavirus disease-19 treatment option. J Med Virol. 2020; 92:556-563.

23. Tang W, Cao Z, Han M, Wang Z, Chen J, Sun W, et al. Hydroxychloroquine in patients with COVID-19: an open label, randomized, controlled trial. BMJ 2020; 369: m1849.
24. Rosenberg ES, Dufort EM, Udo T, Wilberschied L, Kumar J, Tesoriero J, et al. Association of treatment with hydroxychloroquine or azithromycin with in-hospital mortality in patients with COVID-19 in New York State. JAMA 2020; 323 (24): 2493-502.

25. Geleris J, Sun Y, Platt J, Zucker J, Baldwin M, Hripcsak $\mathrm{G}$, et al. Observational study of hydroxychloroquine in hospitalized patients with COVID-19. N Engl J Med 2020; 382 (25): 2411-8.

26. Mahévas M, Tran V-T, Roumier M, Chabrol A, Paule R, Guillaud C, et al. Clinical efficacy of hydroxychloroquine in patients with COVID-19 pneumonia who require oxygen: observational comparative study using routine care data. BMJ 2020; 369: m1844.

27. Cao B, Wang Y, Wen D, Liu W, Wang J, Fang G, et al. A trial of lopinavir-ritonavir in adults hospitalized with severe COVID-19. N Engl J Med 2020; 382: 1787-99.

28. Veronese N, Demurtas J, Yang L, Tonelli R, Barbagallo $\mathrm{M}$, Lopalco $\mathrm{P}$, et al. Use of corticosteroids in coronavirus disease 2019 pneumonia: A systematic review of the literature. Front Med (Lausanne) 2020; 7: 170.

29. Ye Z, Wang Y, Colunga-Lozano L, Prasad M, Tangamornsuksan W, Rochwerg B, et al. Efficacy and safety of corticosteroids in COVID-19 based on evidence for COVID-19, other coronavirus infections, influenza, community-acquired pneumonia and acute respiratory distress syndrome: a systematic review and meta-analysis. CMAJ 2020; 192 (27): E756-67.

30. Wu C, Chen X, Cai Y, Xia J, Zhou X, Xu S, et al. Risk factors associated with acute respiratory distress syndrome and death in patients with coronavirus disease 2019 pneumonia in Wuhan, China. JAMA Intern Med 2020; 180 (7): 934-43.

31. Fadel R, Morrison A, Vahia A, Smith Z, Chaudhry Z, Bhargava $P$, et al. Early short course corticosteroids in hospitalized patients with COVID-19. Clin Infect Dis 2020; doi: 10.1093/cid/ciaa601.

32. Williams D. Clinical Pharmacology of Corticosteroids. Respiratory Care 2018; 63 (6): 655-70.

33. Lee N, Allen Chan K, Hui D, Ng E, Wu A, Chiu R, et al. Effects of early corticosteroid treatment on plasma SARS-associated coronavirus RNA concentrations in adult patients. J Clin Virol 2004; 31 (4): 304-9.

34. Lansbury L, Rodrigo C, Leonardi-Bee J, Nguyen-VanTam J, Lim WS. Corticosteroids as adjunctive therapy in the treatment of influenza. Cochrane Database Syst Rev 2019; 2: CD010406.

35. Horby P, Lim WS, Emberson J, Mafham M, Bell J, Linsell L, et al. Effect of dexamethasone in hospitalized patients with COVID-19- Preliminary report. N Engl J Med 2020; doi: 10.1056/NEJMoa2021436. 
36. WHO Rapid Evidence Appraisal for COVID-19 Therapies (REACT) Working Group, Sterne JAC, Murthy S, Diaz JV, Slutsky AS, Villar J, Angus DC, et al. Association between administration of systemic corticosteroids and mortality among critically ill patients with COVID-19: A meta-analysis. JAMA 2020; e2017023. doi: 10.1001/jama.2020.17023.

37. Schwartz DA. An analysis of 38 pregnant women with COVID-19, their newborn infants, and maternal-fetal transmission of SARS-CoV-2: Maternal coronavirus infections and pregnancy outcomes. Arch Pathol Lab Med 2020; doi: 10.5858/arpa.2020-0901-SA.

38. Shen C, Wang Z, Zhao F, Yang Y, Li J, Yuan J, et al. Treatment of 5 critically ill patients with COVID-19 with convalescent plasma. JAMA. 2020;323(16):1582.

39. QL Zeng QL, Yu ZJ, Gou JJ, Li GM, MA SH, Zhang GF, et al. Effect of Convalescent Plasma Therapy on Viral Shedding and Survival in COVID-19 Patients. J Infect Dis 2020; 222 (1): 38-43.

40. Joyner M, Wright R, Fairweather D, Senefeld J, Bruno K, Klassen S, et al. Early Safety Indicators of COVID-19 Convalescent Plasma in 5,000 Patients. J Clin Invest 2020; 11: 140200.

41. Li L, Zhang W, Hu Y, Tong X, Zheng S, Yang J et al. Effect of convalescent plasma therapy on time to clinical improvement in patients with severe and life-threatening COVID-19. JAMA 2020; 324 (5): 460-70.

42. Gharbharan A, Jordans CCE, Geurtsvan Kessel C, den Hollander JG, Karim F, Mollema FPN, et al. Convalescent Plasma for COVID-19. A randomized clinical trial. medRxiv 2020.07.01.20139857; doi: https://doi.org/10.1 101/2020.07.01.20139857.

43. Li J, Huang DQ, Zou B, Yang H, Hui WZ, Rui F, et al. Epidemiology of COVID-19: A systematic review and meta-analysis of clinical characteristics, risk factors, and outcomes. J Med Virol 2020 Aug 13: 10.1002/jmv.26424. doi: 10.1002/jmv.26424.

44. Kim L, Garg S, O’Halloran A, Whitaker M, Pham H, Anderson EJ, et al. Risk factors for intensive care unit admission and in-hospital mortality among hospitalized adults identified through the U.S. Coronavirus Disease 2019 (COVID-19)-associated hospitalization surveillance network (COVID-NET). Clin Infect Dis 2020; ciaa1012. doi: 10.1093/cid/ciaa1012.

45. Parra-Bracamonte GM, López-Villalobos N, Parra-Bracamonte FE. Clinical characteristics and risk factors for mortality of patients with COVID-19 in a large data set from Mexico. Ann Epidemiol 2020; 14: S10472797(20)30286-6.

46. Wu C, Chen X, Cai Y, Xia J, Zhou X, Xu S, et al. Risk factors associated with acute respiratory distress syndrome and death in patients with coronavirus disease 2019 pneumonia in Wuhan, China. JAMA Intern Med 2020; 180 (7): 934-43.

47. Zhou F, Yu T, Du R, Fan G, Liu Y, Liu Z, et al. Clinical course and risk factors for mortality of adult inpatients with COVID-19 in Wuhan, China: a retrospective cohort study. Lancet 2020; 395 (10229): 1054-62.

48. Shi Y, Yu X, Zhao H, Wang H, Zhao R, Sheng J. Host susceptibility to severe COVID-19 and establishment of a host risk score: findings of 487 cases outside Wuhan. Critical Care 2020; 24 (1): 108.

49. Hu L, Chen S, Fu Y, Gao Z, Long H, Ren H, et al. Risk Factors Associated with Clinical Outcomes in 323 COVID-19 Patients in Wuhan, China. Clin Infect Dis 2020; ciaa539.

50. Ong D, de Man S, Lindeboom F, Koeleman J. Comparison of diagnostic accuracies of rapid serological tests and ELISA to molecular diagnostics in patients with suspected COVID-19 presenting to the hospital. Clin Microbiol Infect 2020; 26 (8): 1094.e7-1094.e10.

51. Cassaniti I, Novazzi F, Giardina F, Salinaro F, Sachs M, Perlini S, et al. Performance of VivaDiag COVID-19 IgM/IgG Rapid Test is inadequate for diagnosis of COVID-19 in acute patients referring to emergency room department. J Med Virol 2020; 10.1002/jmv.25800.

52. Zhou Q, Gao Y, Wang X, Liu R, Du P, Wang X, et al. Nosocomial infections among patients with COVID-19, SARS and MERS: A rapid review and meta-analysis. 2020; Ann Transl Med 2020; 8 (10): 629.

53. Carsana L, Sonzogni A, Nasr A, Rossi R, Pellegrinelli $\mathrm{A}$, Zerbi $\mathrm{P}$, et al. Pulmonary post-mortem findings in a large series of COVID-19 cases from Northern Italy. Lancet Infect Dis 2020; S1473-3099(20)30434-5.

54. Schaller T, Hirschbühl K, Burkhardt K, Braun G, Trepel M, Märkl B, et al. Postmortem Examination of Patients With COVID-19. JAMA 2020; 323(24): 2518-20.

55. Endeman $H$, van der Zee $P$, van Genderen $M$, van den Akker J, Gommers D. Progressive respiratory failure in COVID-19: a hypothesis. Lancet Infect Dis 2020; S14733099(20)30366-2.

56. Paranjpe I, Fuster V, Lala A, Russak A, Glicksberg B, Levin $M$, et al. Association of treatment dose anticoagulation with in-hospital survival among hospitalized patients with COVID-19. J Am Coll Cardiol 2020; 76 (1): 122-4.

57. Tang N, Bai H, Chen X, Gong J, Li D, Sun Z. Anticoagulant treatment is associated with decreased mortality in severe coronavirus disease 2019 patients with coagulopathy. J Thromb Haemost 2020; 18 (5): 1094-9. 